\title{
Riding in the Skin of the Movement: An Agogic Practice
}

\author{
Stephen J. Smith, Simon Fraser University, Burnaby, BC, Canada \\ Email: Stephen_smith@sfu.ca
}

\begin{abstract}
The art of riding imagines the human-horse relation in the image of the centaur. In synchronous motions, riding is a dance of sorts, contact of bodies in the skin of the moment. Yet always there is the possibility of fussing, flailing, falling and failing in moments of resistance, evasion and contrariness. Through phenomenological reflection on such moments, riding can be understood not simply in terms of its difficulties of centaurian mastery, but in terms of the postural, positional, gestural, expressive nuances of interspecies communication. It is on the off beats, and within the syncopations and momentary stresses of riding, that resistance can be addressed through quiet insistence, evasions overcome through persuasion, and contrariness can be felt otherwise. Through contemplation of such moments, we find the reminders of a sensual and essential intercorporeality and the configuration of an agogic practice.
\end{abstract}

\section{Introduction}

Horse riding is a practice, a discipline, and some would claim an art, that is concordant with other somatic practices, disciplines and arts of self-and-other formation. A ready comparison can be made with the movement discipline of "contact improvisation" in terms of the latter's essentially intercorporeal features of "vital contact" (Smith, 2014b). Comparisons can also be ventured with partnered dance forms, a variety of somatic, therapeutic disciplines, martial arts and flow arts, and bodily practices of nature engagement, whether pursued alone or with others (Smith, 2006, 2007; Lloyd, 2011). These comparisons point not only to the practical, bodily means whereby relations to another are constituted, but also to instructive ways in which we can learn to be with another and, indeed, to come into a relationship with an Other who is unlike just any old or young other. For educators, horse riding and related practices, disciplines and arts provide, in particular, contexts from which to reconsider child-centered notions of pedagogy. The adult-child, relational emphasis of pedagogy can, in heeding the "the call of contact" (van Manen, 2012) and in light of the diversity of self-and-other tactful formations that these disciplinary practices afford, shift from the paideia prefix to the agogy suffix. Such a shift of emphasis from the nominal child to the actions of leading another permits us to attend to the gestural, moment-to-moment features of any agogic relationality (Smith, 2012). We come to appreciate "the many ways in which an accent of duration is the essence of [our] most meaningful moments with others" (Smith, 2014b, p. 239) whether they be children, youth or adults and of a human or other-than-human kind.

An educative and broad agogic interest thus undergirds the present study of the aspiration to ride in the skin of the moment. I show this interest, first and foremost, by literally and practically pursuing the art of horse riding, which has essentially to do with balance, timing and feel, and 
which imagines a human and horse connection in the image of the centaur (Thompson, 2011; Game, 2001). Merged as one, horse and rider move together, in unison, and with an animation that neither can alone achieve (cf. Loch, 1997). In frame, cresting at the poll, coming well underneath with bent hocks and lowered hips, loaded as a coil for extended and ballistic movements, responding precisely from imperceptible rider cues and aids, the horse moves with forward impulsion, suppled and straight, on the bit, with contact, and collected from back to front. Image, form and motion come together in a picture of synergistic unity.

The "training scale" or "training ladder" of dressage provides practical guidance in achieving riding excellence (cf. German National Equestrian Federation, 2003; Bryant, 2006). Exercises in the riding school, manage or picadero, emphasizing rhythm, relaxation, contact, impulsion, straightness and collection, over many years move rider and horse to synchronized athleticism. The horse is gymnasticized and schooled in movements that come naturally, yet require years of training to be produced on cue by the rider's most subtle almost invisible aids. Such is the discipline of Grand Prix dressage.

Yet mastery and art are something else again. Consider the brilliance of the modern riding master Nuno Oliveira.

Oliveira enjoyed total mastery of the horse. He could collect and balance a young, fit, unschooled horse within seconds; he had taught horses which had never been trained to changes in their lives, two and even one time flying changes in less than a week; a passable piaffe and passage could be extracted from untalented riding hacks before unbelieving eyes...It was almost as though he rode with an angel at his elbow. It was this total control, this wonderful technique which lent this Portuguese master of our time the quality of greatness. (Loch, 1990, p. 183)

In his riding, with such ability to move the horse, Oliviera followed a modernist tradition of mastery to artistry. This riding tradition has its roots in Ancient Greece, developed alongside other arts of the Renaissance, and encapsulated the evolution of riding from Northern Africa to Iberia, Italy to France, Germany, and England, and from Europe to its colonies under the advance of modernity which was, literally, on the back of the horse.

Xenophon, around 400 B.C.E., wrote instructions on finding a seat, bridling, and taking up the reins such that a rider is not simply on the horse but centered within its movements. These essential features of the "art of horsemanship" (Xenophon in Morgan, 1962) were taken up most thoroughly in the Renaissance ideal of 'perfecting' the horse's nature through systematic schooling. Inspired by the teachings of Antoine de Pluvinel and François Robichon de La Guérinière in the seventeenth and eighteeenth centuries, modern equitation became based on suppling, strengthening, gymnasticizing the horse in increasingly difficult combinations of naturally-occurring movements from the basic gaits of the training school to the airs on and above the ground of the high school. Whether in competitive dressage, training level to Grand Prix, or across the various riding disciplines, Iberian to English to Western to Vaquero, from pleasure riding to the sublime artistry of the Spanish Riding School and the Royal Andalusian School of Equestrian Art, the aspiration remains the same - "centered riding" (Swift, 1985). The twentieth century master Nuno Oliviera who inspired the likes of Michel Henriquet, Charles de Kunffy and Alois Podhajsky, sits atop an enlightenment of equitation that stretches back through the teachings of James Fillis, Francois Baucher, Louis Seeger, Max Ritter von Weyrother, to la Guérinière, Pluvinel, the Duke of Newcastle and the Italians Fiaschi, Grisone, and Pignatelli (see Smith, 2014a). 
But whereas the enlightenment of equitation through to the twentieth century has been brought to us by such notable figures, contemporary environmental and ecological thinking carries a different aspiration than the pursuit of mastery. Let us call this aspiration in the equestrian world what it is, centaured riding, and take it in its post-modern form where there is no longer any instrumental reason to ride a horse. Cavalry, hunting, farming, herding and transport uses have been superseded leaving only recreational pleasures. Horse riding is an end itself; it is an aspiration simply to ride well. The goal whether it be reining, showing, racing, jumping, vaulting, indeed all the riding disciplines, is to achieve a position of perfect alignment, coordination and balance, a disposition of inner and outer equanimity, and a synchronicity of gestures and expressions in seamless communication and wordless agreement. "Good form" is no longer about "judiciousness" in any broad utilitarian sense (cf. Pluvinel, 1626; 1989). It is the desire to become one with the horse.

\section{Beyond Mastery and Control}

Artful riding can be considered a dance of sorts, highly choreographed yet kinaesthetically creative, a contact improvisation of flesh on flesh, calf on girth, pelvic bones pressed to vertebrae, hips flexing in tune with each footfall. It appears as an effortless flow of motions, transitioning seamlessly from trot to canter to walk, half-passing, changing leads, tempi changes, two time, one time, bringing up life in the piaffe and passage, all the while seated securely, deeply, and receiving the gift of the horse's forward motion. But it is also more than a dance. The great Nuno Oliveira wrote:

To practice equestrian art is to establish a conversation on a higher level with the horse; a dialogue of courtesy and finesse. The rider obtains the collaboration of the horse by the slightest hint of a demand, and the spectator can then see the sublime beauty of this communion. He will be touched by the grace and form, and captivated as if he were hearing the most grandiose music. (Oliveira, 1976, p. 18)

Horse riding is the desire to be at one with another being - an at-one-ment, perhaps even an atonement for the rampant individualism characterizing modernity to which Alexis de Tocqueville was one of the first to draw attention (de Tocqueville, 1945). The desire is premised on the sense we have that horse and human are potentially joined in profound interspecies understanding. That understanding is neither "telepathic"(Williams, 2003) nor about "horse whispering" (Evans, 1995); on the contrary, it is manifestly postural, positional, gestural, expressively sensual and visceral, and proprioceptively and kinaesthetically tactful. It is literally an under-standing, an astrideness, or better still, the means of 'finding a seat' that affords the interplay of "vitality affects" (Stern, 2002, 2004, 2010) and the "kinetic-kinaesthetic-affective dynamics" (SheetsJohnstone, 1999/2011, 2009) of interspecies attunement.

'Finding a seat,' with all that this entails technically and attitudinally, allows one to find relaxation, rhythm and contact and, thus, the means of intuiting another's vital functioning. Two bodies, human and horse, are doubly reciprocated. There is reciprocation between each body and its behavior where, as Maurice Merleau-Ponty (2003) put it, "On the one hand, the body is like the envelope, the sketch of behavior; on the other hand, behavior is literally a second body which is added to the natural body" (p. 147). And there is reciprocation between these natural and lived bodies in the lifeworld of horse riding that neither horse nor human can experience alone. Two 
bodies, human and horse, become the outer reference points of an animated, collective consciousness. We discover what is already "all there" and available to us in movement in and through which we can make meaning of ourselves, the horse, and a partnership formed (cf. SheetsJohnstone, 1999, p. 138).

In the skin of the moment is established an intersubjectivity, better still, an inter-corporeity that criss-crosses the species divide and transcends, if only in that moment, the otherness that is felt when consciously rebalancing or assertively controlling the horse. Riding enters the "chiasmic" spaces (Merleau-Ponty, 1968, pp. 130-155)) of momentary overlap and inevitable moment-tomoment separation. The seat of the rider, defined abstractly and dualistically by Paul Belasik (2001) as both "the command center from which directions are issued to the horse" and "as a place to collect data from the horse," is phenomenologically speaking "the intersection of tactile sensations and kinaesthetic sensations and [...] precisely that juncture where all distance is traversed" and where "the flesh of things" and "the flesh of the lived-body" become inseparable (Welton, 1999, p. 45).

The paradigms of control and management with their scientistic, behaviorist and evolutionist prejudices need to be bracketed in order to first appreciate the otherness of another species. By the same token, it is necessary to bracket the implicit assumptions of deferral to the autonomy of another in order to understand an essential, visceral affinity. Consider, for example, what Martin Buber (1947) wrote of his inspiration for contemplating the "I and Thou" relationship:

When I was eleven years of age, spending the summer on my grandparents' estate, I used, as often as I could do it unobserved, to steal into the stable and gently stroke the neck of my darling, a broad dapply-grey horse. It was not a casual delight but a great, certainly friendly, but also deeply stirring happening. If I am to explain it now, beginning from the still very fresh memory of my hand, I must say that what I experienced in touch with the animal was the Other, the immense otherness of the Other, which, however, did not remain strange like the otherness of the ox and the ram, but rather let me draw near and touch it. When I stroked the mighty mane, sometimes marvelously smooth-combed, at other times just as astonishingly wild, and felt the life beneath my hand, it was as though the element of vitality itself bordered on my skin, something that was not I, was certainly not akin to me, palpably the other, not just another, really the Other itself; and yet it let me approach, confided itself to me, placed itself elementally in the relation of THOU and THOU with me. (pp. 26-27)

Buber addresses well the experience of being in the thrall of another being. Yet this remembered experience, this lived experience that is still freshly at hand, carries a desire for the other "that plays out in a tendency to individualize desire and erect an 'other' in order to secure meaning" (Probyn, 1996, p. 40). The horse is cast in the realm of human desire for another being and is at risk of becoming the object of one's own disaffection.

\section{Becoming Horse}

Such desire for the horse, insofar as this desire can be appreciated, recognized and identified in purposeful and planned ways, is the focus of a range of equine-guided education (EGE), equineassisted learning (EAL) and equine-assisted psychotherapeutic (EAP), and facilitated equine enhanced learning (FEEL) programs (see Freewin \& Gardiner, 2005; Hallberg, 2008). It is a 
similar "longing" that underwrites the supposed paradigm shift in the training and rehabilitation of horses (cf. Birke, 2007, p. 233). "Natural horsemanship," "horse whispering," "listening to horses" - these are labels of more benevolent horse training and riding programs. Pioneered in the United States by Tom and Bill Dorrance and Ray Hunt, and popularized by Buck Brannaman, Pat Parelli, Mark Rashid, Stacey Westfall, Clinton Anderson, Ray Lyons, Monty Roberts and Richard Shrake, a multinational horse industry has been created using principles and practices of horsehuman connection and communication based on respect, understanding and partnership-building (see Robert Miller \& Rick Lamb, 2005; and more critically, Birke, 2007, 2008; and Savvides, 2012). Nevertheless, in spite of these more humane approaches, we can still wonder if horses would willingly meet our desires if given a choice.

What of the otherness of "wild or brute being" (Merleau-Ponty, 1968, p. 168), which is an otherness that fits less neatly within deference paid to another being who is posed as the polarity of human identification, or within a captivated otherness that remains in the service of human to horse communication? What of an otherness that breaks out of the subject-object relation? The modern equestrian disciplines, equine-assisted therapies, and even newer benevolent ways of responding to horses, are challenged by a postmodern sensibility. 'Gentling' that rightly replaced 'breaking' a horse gives way to eco-phenomenologically-addressed sensitivities that attune human kinaesthetic consciousness to the animate and highly developed movement consciousness of the horse (cf. Kiley-Worthington, 2005). We countenance an otherness that incorporates the "physical" and the "vital orders" of existence not simply in the "human order" (cf. Merleau-Ponty, 1963), but within a physical, vital, phenomenal, "more-than-human consciousness" (Abram, 1996; 2010).

Elspeth Probyn (1996) wrote of "becoming horse" as the movement of desire constantly refashioning its own object reference (pp. 37-60). Becoming horse "[turns] away from the game of matching signifiers to signifieds" and concerns itself with "the movement of images as effecting and affecting movement" (p. 59). It designates a "moment of valency," a moment "in-between" the image held and the imagination of becoming horse. Probyn writes: "Although it could suggest a certain romanticism of becoming one with the animal, it is...a rudely impersonal state" (p. 51). Referencing the work of Giles Deleuze and Felix Guattari:

It is the determination of becoming, its proper power, the power of an impersonal which is not a generality, but a singularity at its highest: for example, one does not do the horse, no more than one imitates such a horse, but one becomes $a$ horse, in attaining a zone of proximity where one can no longer be distinguished from what one becomes. (Probyn, 1996, p. 51; see Deleuze and Guattari, 1987, pp. 232-309)

Yet something is missing of the Other in this desire of becoming horse. Take, for example, a description of becoming horse provided by Alphonso Lingis. Lingis's invariably sensual and sexual descriptions disclose the movement of desire as it approximates not so much a "rudely impersonal state" as a state of sensuous and interspecies arousal. "Bestiality" is what Lingis calls it in describing this and the manifold reminders that we are incarnately, carnally, more-than-human beings.

A woman riding a horse pumps with the surges of its impulses, while the horse's pace incorporates her shifts and pulls. The movements of her body extend speed and retardation, and feel the thrill of speed and the soothing decompression of slowing down. 
These movements extend neither toward a result nor a development. They are figures of the repetition compulsion... we ride a horse through the woods with the utterly noncumulative recurrence of orgasm. (Lingis, 2000, p. 31; also Lingis, 2001, p. 169).

We thus arrive at a post-modern predicament. Modernity carries forward the disciplines of horse management, riding and, indeed, equestrian art, to be at one with the horse, centered, centaured, in perfect movement synchrony. By the same token, modern methods of horse training and riding carry the legacy of the enlightenment in the felt tension of a partnership of trust that is still determined by rider control and ostensibly the domination of another's will. The predicament in which we find ourselves as riders who seek to really know the horses we ride in their individualities, their particular temperaments, and distinctive manners of being with us and with others of their own kind, is not that these horses lose their identities within training systems to which we subject them and, most notably, when we seek to 'perfect' their movements through the training pyramid of dressage. In fact, horses at the apex of the pyramid and competing in World Cup and Olympic competitions become household names to the equestrian public. The predicament is more a matter of connecting with another being in the mood and manner of "transpecific conviviality" (Acampora, 2006, pp. 30, 93; also Smith, 2015) that the bodily mode of riding both constrains and affords.

But what of this has to do with "wild or brute being" and with the horse as a being with its own desires? Images, not just of mythological centaurs, but also of wild horses, mustangs and brumbies, come to mind. This imagery invariably plays, however, upon the very desires of becoming horse that have valorized wildness and brute being. What, then, of horse riding and training, and the legacy of the enlightenment, will allow for becoming horse in the motile play of desires that return to the senses and "elemental flesh" of "wild being" (Merleau-Ponty, 1968)? Do we await another paradigm shift that might resolve this predicament? Or does the post-modern turn to wild being, as a somewhat paradoxical recognition, call for a return to a phenomenology of being in the skin of the moment such that becoming an artful rider, if not "becoming horse" in either the "rudely impersonal state" Probyn imputes to it or in the erotic sense that Lingis describes, carries the senses of another being and the sensitivity to becoming one with an Other within "a 'wild Region' as the zone of interconnected species meaning" (Dillard-Wright, 2009, pp. 46-48).

I am proposing that it is within the regional ontology of horse riding and training that the most practical hints of becoming horse and thus becoming more fully ourselves in partnership with our horses can be discerned. Our most telling experiences may, in fact, be those in which we actually experience kinetically, kinaesthetically and affectively a sense of 'wildness' and where bodily control of another being, our otherwise manageable and rideable horse, is crucially in question.

\section{The Hippagogic Moment}

When riding horses, there is the ever-present possibility of being unbalanced, out of sync, even out of the saddle, and falling hard in moments of resistance, evasion and contrariness. Such moments are evident breaks in human-horse communication and, specifically, they indicate limits to the postural, positional, gestural, and expressive synchronizations that a somewhat shared nonverbal language at other times affords. Such moments seem to attest, in addition to these kinesic dissonances, to a haptic noncontemporaneity, which is to say, to a touch that is momentary out of touch, and to a proxemic distance pitting horse and rider against one another. Yet are these 
moments to be considered so contrastively with the moments of synchronous movement when, "[w]ithin this mutual cross-species embodiment of movement, rider and horse each, at times, follow and lead, as in a dance" (Argent, 2012, p. 119; see, also, Smith, 2015 in press)?

There is rhythmicity to riding well such that one feels in the skin of the moment, the hippagogic moment, the off beats, syncopations and arrhythmias of shortened steps, speed changes, false bends, and stiffened gaits. There are moment-to-moment adjustments in all facets of the riderhorse-technology-space complex that are needed in order to maintain the "isorhythmia" of this complex (Evans and Franklin, 2010, p. 183). Indeed, it may well be that we desire the "floating moment....which exists almost as a standing wave constructed out of all the component rhythmicities which have produced it" (p. 185), though the moments of riding are often of a more turbulent kind.

\section{Falling out of the Moment}

I am riding in the outside dressage arena on a blustery, noisy afternoon. Pastures alongside are being mowed, intermittent gun shots fired in nearby blueberry farms scatter flocks of Starlings, while in the arena other riders and their horses are in motion. My horse, Mojo, feels the commotion, distractedly, going forward but tracking rigidly, steeling himself to the concerns swirling about. I slow him to a walk, calming him through the rhythmicity of the gait when, suddenly, explosively, the revving of an engine nearby fires his legs into scurried motion. He shies, scoots and, before I can hold him, bolts across the arena. I try to wheel him round, turn his head and disengage his hindquarters, but this unbalances him and forces a further clamping of the jaw on the bit and a collapse on the outside shoulder. He begins to crumble forward, racing over the front end, trying to get under the weight of himself with me atop. I am unseated, pitching forward, toppling, cartwheeling with no place to go but the ground.

I land ungainly. Hard. Stunned. I try to stand, but crumple again to the ground.

Mojo is retrieved, brought to me panting, snorting, prancing, his ears and eyes still darting around the arena.

"Can you get back on?" asks the one leading him.

No, I am hurt, injured again in my knee, good only to limp to the stable, put my horse away, and feel the extent of injury.

I think much about this event during a long convalescence. I think about it months later when I again ride Mojo. I think of the moment, perhaps more than one, when, prior to my horse bolting, a different possibility was offered. There was a moment I missed to rebalance, find my seat, redirect and reconnect to the energy of an anxious horse. There were moments of tension building. There was also a fleeting moment before the fall when things might have gone otherwise. In search of that moment, those moments, I turn again to the example of Nuno Oliveira and a riding event that Paul Belasik (2001b) witnessed.

At one end of his indoor school is an observation room. It has windows along its entire length so quite a few people can observe at once. From the windows there is roughly an eight-feet drop to the riding-hall floor. On this particular day the weather is terrible, and it happened that I was the only person in the observation room and Nuno was the only person riding. He was working a young grey stallion through some lateral work at the trot, and in the last few days he had been teaching this young horse the flying changes during the canter work. Very quickly the sky became dark. His methodic work continued quietly. The air 
became so still that it was easy to hear the horse chewing the bit even when it was at the farthest end of the school. Suddenly, in one flash a storm erupted. Lightening crackled and sheets of hail-like rain pounded the thin metal roof of the arena. The grey horse exploded and began blazing around the arena in half spins and huge leaps. As they passed in front of me, the horse caprioled right up alongside the windows. Oliveira was inches from me, flying through the air. The thunder crashed and the roof sounded as though it would collapse at any moment. The horse became even more frenzied, and went tearing around the hall again. Mr. Oliveira's face was turning deeper and deeper shades of red. I was certain that in another second he was going to be thrown, and thrown hard....the horse and Oliveira went by again, as much in the air as on the ground. Amazingly, throughout this performance his position hardly moved. He sat bolt upright. Only his extremely flushed face and his surprised eyes revealed his effort to stay on board. Finally, after what seemed like at least three or four full minutes, he settled the horse down. (pp. 77-78)

The different outcomes of my and Oliviera's experiences with spooked horses can be explained easily enough by our differing skill levels. There are techniques for halting a young, insecure, frightened horse (cf. Parelli, 1993; Podhajsky, 1967a, pp. 21-26) that I might have used. So, once back in the saddle and as a safety precaution, I ride for a while with brakes, which take the form of a Running Martingale (a set of leveraged straps anchored to the girth strap through which the reins are threaded) that give me added control of Mojo's head and neck, and with a deeper saddle to better anchor my seat. I ride my horse for a while under the supervision of a horse retrainer who helps me 'break' Mojo of his flighty ways. I learn to have Mojo face his fears, hold his ground and, should he try to flee, I am able to turn him in calming, controlling circles.

But beyond matters of skill and technique, the difference between falling and keeping one's seat speaks to a different relation to the horse in the moments before the effort to halt the horse's motion is invariably either too-little-too-late or too-much-too-soon. What sensitivities to 'wildness' may better achieve a relation of confidence in the horse and the horse's confidence in the rider? What actions are fundamentally conscious of "an unfolding kinetic dynamic" and of the "primordial constitution of time" (Sheets-Johnstone, 1999, p. 142; 151-162) as the essence of riding well?

\section{Half-halting}

There is a 'half-halt' in riding, which is really a misnomer because the rein action, far from halting the horse, serves rather to animate the gait and bring impulsion to the moment. The stop, the pause, has a different effect, necessary for choice, reflection and the phenomenology of lived experience, but it ought not be confused with the go, the yes, and movements that are on the spur of the moment, actually in the moment, and that issue from a well-timed half-halt. Technically, the half-halt is a momentary arrest of motion through slightly increasing the tension in the reins, squeezing calves and thighs, stilling the seat, tensioning abdominals and back, as if loading a spring for what is, in much the same moment, a surge forward into a revitalized gait. The horse comes under himself with power rebalanced on lowered, driving hindquarters.

The half-halt, technically a "call to attention," prepares the horse for ensuing aids (Podhajsky, 1967 b, p. 40). A correctly executed half-halt is, however, much more than a technically proficient action. Its effectiveness rests on a sensitivity, a kinaesthetic awareness, of the nuances of animation that technique alone cannot bring. 
If it is in the seat that the rider begins to find his own centre of balance and thus awareness, then in the half-halt this awareness will send the rider deeper into the horse, where he will be able to sense something of the horse's centre of balance. Ultimately horse and rider will come to a place where they will emerge into something quite new: a place, a feeling, where the rider will literally be at one with the horse. (Belasik, 2001b, p. 43)

We thus come back to the appeal of synchronicity and the desire of becoming horse, now with a means of achieving it. But we do not have a generalizable method other than a rough outline of actions that take rider and horse into a moment when what is actually called for can be felt. François Robichon de La Guériniere (1733/1994) advised: "Thus the half-halt suits all types of horse; but there are certain natures which require its judicious use" (p. 132). Judiciousness concerns what Guériniere called the "character" of the horse, whether the horse is forward-going or hesitant and phlegmatic. Such concern we may now describe as a sensory and essential attunement to the animation of the horse, its vitality, and a kinaesthetic consciousness of subtle changes of posture, position, gesture and expression that revitalize the complexion of the horse's gaits.

The half-halt is a kind of "syncope" (Clément, 1994). It is a temporal suspense in anticipation of the next moment. It begins on the "weak beat and carries over to a strong beat" (p. 4) and in this syncopation it "seems to accomplish a miraculous suspension" (p. 5). Carrying the musical reference further, we could say that the half-halt is also a momentary stress, an agogic accent that restores a rhythmic balance and literally enables a passage of notes or, say, a passáge in dressage, to become more lively, more impulsioned, more surely cadenced.

\section{The Vital Moment}

Riding is a series of enlivening moments - half-halts, collections, and transitions. But sensitively, sensuously, desirously, riding is of the moment, in the moment, vitally, corporeally, intercorporeally. Riding is all timing, feeling the rhythm, and making, creating time. Karl Mikolka, former head rider of the Spanish Riding School, writes,

Tenth DAN and founder of Doshinkan-Karate-Do, Ichikawa loved horses and in exchange for riding lessons, taught me the mysteries of Far Eastern Philosophy and empty hand skills. Through Hanshi's guidance I acquired an improved understanding for developing a physical and mental balance second to none in all of my horses and as a result was able to respond to their inner feelings in a way I never thought possible. Hanshi stressed the study of kata-disciplined basics until they became second nature. He once explained that throughout the years of hard training he cultivated the ability to stretch time. A second for the average person became six seconds for the Master. Years later, while riding a horse in Brazil that required quick actions, I suddenly felt that I too could stretch time and the words of the Master became reality for me. Being able to stretch time is the ultimate form of relaxation. The skill to respond to the unexpected actions of a horse with ultimate calmness, almost in slow motion, is one of the miracles of high-level riding. (Molika, 2007)

Stretching time is reminiscent of writings on the psychology of flow, deep play and peak experiences (e.g. Lloyd and Smith, 2006), the premise of which is that chronos time is the normal order of life against which exceptional moments of temporal transcendence occur. Riding helps us 
realize such moments that constitute time as intuition, insight, contact and connection are not so much stretching a duration, as finding that, in the elasticity of vital contact with the motions of the horse, there is all the time in the world.

A horseman by the name of Klaus Hempfling brings out the most wonderful responses from his horses, all on a loose rein and mostly with no reins at all. He rides as if "dancing with horses" (Hempfling, 2001). He practices an artistry of "natural balance" premised on attaining a collected state without coercion or force, but only through bodily communication in postures, positions, gestures and expressions (see also Hempfling, 2010, 2013). And yet his emphasis on human dominance is troubling, harking back to a history of interspecies connections that asserts our human dominion over nature. Still, Hempfling alerts us to a hippagogic practice that is attuned to the vital moment and that shows the means of elasticizing it. His means is a body language that flexes and supples the horse, bends and stretches the moment to moment engagement, and that makes riding into a dance and an art.

The loose rein Hempfling advocates allows neither the rider to pull against the horse nor the horse to steel himself and use his much greater force against the rider. It allows, more positively, the communication of subtle, nuanced movements as vibrations from human hand to horse's head. It divines the emotions of another being in the feel of its motions. A loose rein spares the whip, not to spoil the horse; on the contrary, it is "antiauthoritarian" (Hempfling, 2001, p. 188) in abstaining from holding the other on a tight rein that would maintain a subjugation and the simmering resistances, inevitable evasions and challenges that such control provokes. 'Reining in' is replaced by a lighter, softer touch.

Slowly, too, I am loosening my grip, my apprehension, comprehension, tight grasp, so that I can better understand this way of making "vital contact" (cf. Smith, 2014b). On a freely giving 'soft' rein, laying off my hands, I am making contact with a potentially unbridled agogic truth that becoming horse is more than the grasping actions of human desire; it is a gift received with pliant, open hands.

I play initially with this soft contact, riding bareback in the snow, on just a loose lead attached to the halter. I practice softness in "liberty training" (Smith, 2011, 2014a) and in divining "coenesthetic connection" (Smith, 2015) within the instructional system of FEI (Fédération Equestre Internationale) dressage. Cues for movement must come from the finely tuned postural and positional changes, from the challenge to make gesturing be of the legs and pelvis rather than of the hands and arms, and to admit to expressioning and complexioning the gaits through balance, feel and timing. It is the near realization of becoming horse, of moving as one body, not in the other or the other in me, but in the elastic, motile skin of the moment.

\section{Conclusion}

Durational accents, attuned to pulse and rhythm, constitute a riding discipline of attentiveness. The agogic accent, as reflected in the half-halt, underlines the science and art of receptivity to vital energies and that, within the broader context of disciplines and practices of being attuned to the flesh of another being, admits an instruction in becoming increasingly mindful not of the nominal Other (which is represented by THE horse) but of so many flesh-and-blood, animate others (including particular horses such as Mojo).

Schooling horses and learning the postures, positions, gestures, expressions and complexions of riding is, more than technique, even more than art, a way of being other than humanly-contained and, indeed, other than restrictively human. In the skin of the moment, with durational, agogic 
accent, syncope, half-halts, one brings up the life of two beings. We turn from a modernist rendition of riding to a post-modern play of desires of becoming horse only to return to an essential corporeality and a sensual, sensitive, sensing intercorporeality that still admits classical principles of training (Smith, 2014a). The difference that makes all the difference, and that which makes art and philosophy out of skill and technique, is the desire to become horse in the kinaesthetic sense of animating, and being animated by, the movements of another being.

The almost universally-adopted training scale of dressage (German National Equestrian Federation, 2003) can thus be reconceptualized as a progression not simply from Training Level movements to Grand Prix performances, but more significantly as registers of interspecies communication. The scale is first an emphasis on rhythm and relaxation which is about breathing, suppling, strengthening, energizing horse and rider into enlivened co-presence. Next it is about contact, con-tacting, touching and being touched, sensing, feeling, resonating, reverberating, and intuiting a responsive contemporaneity. Impulsion is about kinaesthetic attunement to the rushing, bursting, ebbing, charging, pulsing vitalities of synchronization. Straightness is about the momentto-moment achievements of good form, which is the desired aesthetic frame, through the laterality, verticality, circularity and ultimately the directionality of cadenced duration. And finally, collection is about walking, trotting, cantering, half-passing, gait transitioning, changing leads, passáging, and piaffing with gathered, energetic flow.

These phenomenological registers of the dressage training scale - as co-presence, contemporaneity, synchronization, duration and flow - draw attention to the living experience of an interspecies relation that is essentially and ecstatically temporal. At the same time, let us not lose sight of the fact that riding in the skin of the moment, as an agogic practice, provides a set of temporal registers for other disciplinary practices that are concordant with the desire to become one with another sentient being while bearing due responsibility for the other's present and future well-being. Co-presence, contemporaneity, synchronization, duration and flow can evoke and provoke, beyond any specific, disciplinary training scale involving humans and horses, a more universalized temporality of attunement and responsiveness to an Other.

Riding well requires much study, much preparation, much practice, and even more practice. It requires cultivating balance, feel and timing over many, many years and under instruction that is so very demanding of horse and rider. The best instructor is the "schoolmaster" -the seasoned horse that knows the movements and their aids and can teach a rider how best to apply them. But all instruction, whether from a schoolmaster horse or a human coach, can only be preparatory for the moment of "judiciousness," as Guérinière called it, when rider and horse become centered amidst the desire to be centaured. Acting on the spur of the moment misses this moment, placing metal prods into the horse's flanks in a corrective move. Riding in the skin of the moment, however, spurs horse and rider on as a temporality that is synergistically, intercorporeally constituted. This is riding with skill, finesse, artistry and sensitivity to movements that, in the moment, enjoin rider and horse in the flesh. Two beings become as one, becoming horse, becoming human, in elemental and always potentially wild connection.

\section{References:}

Abram, D. (1996). The spell of the sensuous: Perception and language in a more-than-human world. New York: Vintage Books.

Abram, D. (2010). Becoming animal: An earthly cosmology. New York: Pantheon Books. 
Acampora, R.A. (2006). Corporal Compassion: Animal ethics and philosophy of the body. Pittsburgh: University of Pittsburgh Press.

Argent, G. (2012). Toward a privileging of the nonverbal: Communication, corporeal synchrony, and transcendence in humans and horses, in Experiencing animal minds: An Anthology of animal-human encounters, edited by J.A. Smith and R.W. Mitchell. New York: Columbia University Press, 111-128.

Belasak, P. (2001). Dressage for the $21^{\text {st }}$ century. London: Trafalgar Square.

Belasak, P. (2001b). The essential Belasak: Riding towards the light, exploring dressage technique, the songs of horses. North Pomfret, VT: Trafalgar Square.

Birke, L. (2007). "Learning to speak horse": The culture of natural horsemanship, Society \& Animals, 15 (3), 217-239.

Birke, L. (2008). Talking about horses: Control and freedom in the world of "natural horsemanship," Society \& Animals, 16 (2), 107-126.

Bryant, J. O. (2006). The USDF guide to dressage. North Adams, MA: Storey.

Buber, M. (1947). Between man and man (R. Gregor-Smith, Trans.). London: Routledge.

Clément, C. (1994). Syncope: The philosophy of rapture (translated by S. O'Driscoll and D. M. Mahoney). Minneapolis: University of Minnesota Press.

De la Gueriniere, F. R. (1773/1994). School of horsemanship (T. Boucher, Trans.). London: J.A. Allen.

de Tocqueville, A. (1945) Democracy in America, vol. 2. New York: Alfred A. Knopf, pp. 9899. Retrieved May 20, 2015 from:

http://static.sewanee.edu/faculty/Willis/Civil_War/documents/TocquevilleIndividualism.html

Deleuze, G. and Guattari, F. (1987).A thousand plateaus: Capitalism and Schizophrenia (B. Massumi, Trans.). Minneapolis: University of Minnesota Press.

De Pluvinel, A. (1626/1989). The Maneige Royal (H. Nelson, Trans.). London: J.A. Allen.

Dillard-Wright, D.B. (2009). Ark of the possible: The animal world in Merleau-Ponty. Lanham, MD: Lexington Books.

Evans, N. (1995). The horse whisperer. New York: Dell.

Evans, R. and Franklin, A. (2010). Equine beats: Unique rhythms (and floating harmony) of horses and riders, in Geographies of rhythm: Nature, place, mobilities and bodies, edited by T. Edensor. Surrey, UK: Ashgate.

Freewin, K. and Gardiner, B. (2005). New age or old sage: A review of equine assisted psychotherapy, The Australian Journal of Counselling Psychology, 6, 13-17.

Game, A. (2001). Riding: Embodying the centaur, Body and Society, 7, 1-12.

German National Equestrian Federation (2003). The principles of riding. Addington, UK: Kenilworth. 
Hallberg, L. (2008). Walking the way of the horse: Exploring the power of the horse-humanrelationship. New York: iUniverse, Inc.

Hempfling, K. F. (2001). Dancing with horses: Collected riding on a loose rein. North Pomfret, VT: Trafalgar Square.

Hempfling, K.F. (2010). The horse seeks me. London: Cadmos.

Hempfling, K. F. (2013). What horses reveal: From first meeting to friend for life. Pomfret. VT: Trafalgar Square.

Kiley-Worthington, M. (2005). Horse watch: What it is to be equine. London: J.A. Allen.

Lingis, A. (2000). Dangerous emotions. Berkeley: University of California.

Lingis, A. (2001). Animal body: Inhuman face, in Zoontologies: The question of the animal, edited by G. Wolfe. Minneapolis: University of Minnesota Press, 165-182.

Loch, S. (1990). Dressage: the art of classical riding. North Pomfret, Vermont: Trafalgar Square.

Loch, S. (1997). The classical rider: Being at one with your horse. North Pomfret, Vermont: Trafalgar Square.

Lloyd, R.J. (2011). Awakening Movement Consciousness in the Physical Landscapes of Literacy: Leaving, Reading and Being Moved by One's Trace, Phenomenology \& Practice, 5(2), 70-92.

Lloyd, R. J. \& Smith, S. J. (2006). Interactive flow and exercise pedagogy, Quest, 58, 222-241.

Merleau-Ponty, M. (1963). The structure of behavior (A.L. Fisher, Trans.). Pittsburgh: Duquesne University Press.

Merleau-Ponty, M. (1968). The visible and the invisible (A. Lingis, Trans.). Evanston: Northwestern University Press.

Merleau-Ponty, M. (2003). Nature: Course notes from the College de France (R. Vallier, Trans.). Evanston, Illinois: Northwestern University Press.

Miller, R. and Lamb, R. (2005). The revolution in horsemanship and what it means to mankind. Guilford CT: The Lyons Press.

Molika, C. (2007). Some of my teachers. Retrieved May 2012 from http://www.karlmikolka.com/teachers.php

Morgan, M. H. (1962). The art of horsemanship by Xenophon. London: J.A. Allen.

Oliveira, N. (1976). Reflections on equestrian art. London: J.A. Allen.

Parelli, P. (1993). Natural horsemanship. Colorado Springs, CO: Western Horseman.

Probyn, E. (1996). Outside belongings. New York: Routledge.

Podhajsky, A. (1967a). My horses, my teachers. North Pomfret, VT: Trafalgar Square.

Podhajsky, A. (1967b). The complete training of horse and rider: The principles of classical horsemanship. Hollywood, CA: Wilshire. 
Savvides, N. (2012). Communication as a solution to conflict: Fundamental similarities in divergent methods of horse training, Society \& Animals, 20 (1), 75-90.

Sheets-Johnstone, M. (1999/2011). The primacy of movement (and expanded second edition). Amsterdam: John Benjamins.

Sheets-Johnstone, M. (2009). The corporeal turn: An interdisciplinary reader. Exeter, UK: Imprint Academic.

Smith, S.J. (2006). Gesture, landscape and embrace: A phenomenological analysis of elemental motions, Indo-Pacific Journal of Phenomenology, 6(1), 1-10.

Smith, S.J. (2007). The first rush of movement: A phenomenological preface to movement education, Phenomenology \& Practice, 1(1), 47-55.

Smith, S.J. (2011). Becoming horse in the duration of the moment, Phenomenology \& Practice, $5(1), 7-26$.

Smith, S.J. (2012). Caring caresses and the embodiment of good teaching, Phenomenology \& Practice, 6(2), 65-83.

Smith, S.J. (2014a). "Human-horse partnerships: The discipline of dressage," in Sport, animals, and society, edited by J. Gillett and M. Gilbert. New York: Routledge, 35-51.

Smith, S.J. (2014b). A pedagogy of vital contact, Journal of Dance and Somatic Practices, 6(2), 233-246.

Smith, S.J. (2015 in press). Dancing with horses: The science and artistry of coenesthetic connection, Domestic animals and leisure, edited by N. Carr. London: Palgrave MacMillan.

Stern, D. N. (2002). The first relationship: Infant and mother. Cambridge, MA: Harvard University Press.

Stern, D.N. (2004). The Present Moment in Psychotherapy and Everyday Life. New York: W.W. Norton \& Company.

Stern, D. (2010). Forms of vitality: Exploring the dynamic experience in psychology, the arts, psychotherapy, and development. Oxford: Oxford University Press.

Swift, S. (1985). Centered riding. North Pomfret: Trafalgar Square.

Thompson, K. (2011). Theorizing rider-horse relations: An ethnographic illustration of the centaur metaphor in the Spanish bullfight, in Theorizing animals: Re-thinking humananimal relations, edited by N. Taylor and T. Signal. Leiden: Koninklijke Brill, 211-253.

van Manen, M. (2012). The call of pedagogy as the call of contact, Phenomenology \& Practice, $6(2), 8-34$.

Welton, D. (1999). Soft, smooth hands, The Body: Classic and Contemporary Readings, edited by D. Welton. Oxford: Blackwell, 38-55.

Williams, M. (2003). Learning their language: Intuitive communication with animals and nature. Novato, CA: New World Library. 